\title{
Carcinoma-in-Situ of the Vulva in a Developing Community
}

\author{
Wilson I B Onuigbo* \\ Department of Pathology, Nigeria
}

Submission: December 15, 2016 ; Published: January 17, 2017

*Corresponding author: Wilson I B Onuigbo, Department of Pathology, Medical Foundation and Clinic, 8 Nsukka Lane, Enugu 400001, Nigeria, Email: wilson.onuigbo@gmail.com

\begin{abstract}
The vulva is a distinct anatomical female organ that has merited attention for long. From the 1970s, many cases of cancer at the in-situ stage had been published from mostly American centers with emphasis on local vulvectomy treatment. Therefore, this paper dwells on 6 cases collected in a Regional Pathology Laboratory patronized by women of the Igbo ethnic group who are living in a developing community in Nigeria. This was thanks to the auspicious establishment of a local histopathological data pool. It is to be noted that there was no follow up, the analysis being limited to basic clinical data.
\end{abstract}

Keywords: Vulva; In-situ cancer; Data pool; Epidemiology; Developing community

\section{Introduction}

An important paper was published recently from the Memorial Sloan-Kettering Cancer Center [1]. Its message included partial superficial skinning vulvectomy. Therefore, this paper dwells on vulvectomy specimens collected from the Ibo/Igbo ethnic group [2], who are domiciled in a developing community in South-eastern Nigeria. Thanks to the establishment of a Regional Pathology Department in its Capital city, Enugu, the author was able to use its histopathology data pool as was recommended by a Birmingham (UK) group as being fit for epidemiological analysis [3].

\section{Investigation}

A typical example may be given as well as tabulated data.

\section{Case Report}

OC, 30-year-old woman, presented with vulval swelling of a year's duration. The growth was slow and not painful. On examination, there was a firm, non-tender swelling in the left labium majus. This was completely excised. The $5 \times 2 \times 1.5 \mathrm{~cm}$ polypoid mass was received personally. Microscopy revealed much thickened epidermis. Mitotic figures abounded in all its layers. However, transgression of the basement membrane was not evident. Excision appeared complete and carcinoma-in-situ was diagnosed.

\section{Results}

The ages ranged from 30 to 52 years (average 47 years). One case was provisionally diagnosed as Lichen Sclerosus but the rest were suspected to be cancerous. Of the centers from which the specimens were submitted, half was from Enugu and the rest from Missionary Hospitals (Table 1).

Table 1: Epidemiological data on vulvar carcinoma-in-situ in a developing community.

\begin{tabular}{|c|c|c|c|c|c|c|c|}
\hline S/No & Labe No & Initials & Age & Parity & Symptom & Diagnosis & Town \\
\hline 1 & H $459 / 83$ & EF & 45 & - & Itching & Cancer & Afikpo \\
\hline 2 & $\begin{array}{c}\text { UH } \\
279 / 89\end{array}$ & OA & 51 & 0 & Itching & $\begin{array}{c}\text { Lichen } \\
\text { sclerosus }\end{array}$ & Enugu \\
\hline 3 & $\begin{array}{c}\text { UH } \\
453 / 90\end{array}$ & AV & 55 & 8 & Ulcer & $\begin{array}{c}\text { Early } \\
\text { cancer }\end{array}$ & Nsukka \\
\hline 4 & $\begin{array}{c}\text { UH } \\
2747 / 90\end{array}$ & OC & 30 & - & Swelling & Cancer & Enugu \\
\hline 5 & 9202165 & AV & 50 & 8 & Wound & Cancer & Enugu \\
\hline 6 & $971 / 91$ & CR & 52 & 12 & Ulcer & Cancer & Afikpo \\
\hline
\end{tabular}

\section{Discussion}

The last named hospitals are indicative of the role of foreigners in health services in a developing community. How do the derived data compare with worldwide experience? There is the question of the accuracy of the diagnosis [4]. Needless to say, the author personally made it. Concern about multiplicity 
and occult invasion has led authorities to recommend total vulvectomy in the management of carcinoma in situ of the vulva [5]. In my experience, mostly small pieces scarcely up to $5 \mathrm{~cm}$ across were submitted.

A large group has been followed from 1 to 15 years [6] or with relation to results obtained with various treatment methods [7]. In the present group, this was not done.

\section{References}

1. Gupta N, Rodriguez E, Andikyan V, Salob SP, Chi D (2013) A case report of vulvar carcinoma in situ treated with sinecatechins with complete response. Gynecol Oncol Case Rep 6: 10-12.
2. Basden GT (1966) Niger Ibos Cass, London.

3. Macartney JC, Rollaston TP, Codling BW (1980) Use of a histopathology data pool for epidemiological analysis. J Clin Pathol 33(4): 351-355.

4. Woodruff JD, Julian C, Puray T, Mermut S, Katayama P (1973) The contemporary challenge of carcinoma in situ of the vulva. Am J Obstet Gynecol 115(5): 677-686.

5. Forney JP, Morrow CP, Townsend DE, Di Saia PJ (1977) Management of carcinoma in situ of the vulva. Am J Obstet Gynecol 127(8): 801-806.

6. Buscema J, Woodruff D, Parmley TH, Genadry R (1980) Carcinoma in situ of the vulva. Obstet Gynecol 55(2): 225-230.

7. Friedrich Jr EG, Wilkinson EJ, Shifu Yao (1980) Carcinoma in situ of the vulva: A continuing challenge. Am J Obstet Gynecol 136(7): 830-843.

\begin{tabular}{l} 
Your next submission with Juniper Publishers \\
will reach you the below assets \\
- Quality Editorial service \\
- Swift Peer Review \\
- Reprints availability \\
- E-prints Service \\
- Manuscript Podcast for convenient understanding \\
- Global attainment for your research \\
- Manuscript accessibility in different formats \\
( Pdf, E-pub, Full Text, Audio) \\
- Unceasing customer service \\
Track the below URL for one-step submission \\
https://juniperpublishers.com/online-submission.php \\
\hline
\end{tabular}

